\title{
Melanoma of the Uvea cM1 TNM Finding v7
}

National Cancer Institute

\section{Source}

National Cancer Institute. Melanoma of the Uvea CM1 TNM Finding v7. NCI Thesaurus.

Code C88720.

Melanoma of the uvea with distant metastasis. (from AJCC 7th Ed.) 